\title{
BIRDS
}

\section{BIRD OBSERVATIONS FROM NORTHERN SASKATCHEWAN, AUGUST 1973}

\author{
WAYNE E. RENAUD, 9 Oakwood Avenue, N. Mississauga, ON L5G 3L6
}

The first organized study of the birds of northern Saskatchewan, was conducted by $\mathrm{Nero}^{3}$. While concentrating on the Lake Athabasca area of northern Saskatchewan, preliminary visits were made to Stony Rapids and Black Lake (1960 to 1962) and Hasbala Lake (27 July to 3 August), the most northeasterly lake in Saskatchewan. From 1963 to 1965 , Nero focused his studies on the lichen woodlands and muskegs to northeastern Saskatchewan: 26 June to 31 July 1963 (Stony Rapids/Black Lake), 9-29 July 1963 (Hasbala, Patterson and Warren Lakes), 1-14 July 1964 (Milton Lake and Porcupine Rivers); 18-24 July 1964 (Charcoal Lake); 20 April to 8 July, 1964 (Wollaston Lake), and 27 June to 27 July 1965 (Reindeer Lake) 4 . Later, in 1977, studies by Secoy and Maw were undertaken from 28 May to 16 August at Boland Lake, Higgins Lake, Nekweaga Bay at the southern tip of Wollaston Lake: they recorded an mpressive total of 77 species $^{6}$. To date, hese appear to be the only published work based on long-term ground-based ornithological research programs, from his, the most remote and least accessible area of Saskatchewan.

In the summer of 1973 , the author and lohn Rowe, Jr. embarked on studies of are and representative plant cosystems in Saskatchewan. These tudies were part of 'The International Biological Program'[IBP] which were funded through the Department of Plant Ecology, University of Saskatchewan, Saskatoon and conducted under the supervision of Dr. J.S. Rowe. Three 'IBP' sites were located in the extreme northern and northeastern areas of the province, and within the study area of 'The Birds of Northeastern Saskatchewan'. These unpublished records were made from 8 to 24 August 1973.

Although the documentation of birds was not the focus of our study, I diligently recorded all the birds which were observed during our visit. The records of birds presented here were made in the following areas: Lefty Falls and Stony Rapids on the Fond du Lac River (59-16'N; $105-50$ 'N), Fir Island/Black Lake (59-11'N; $\left.105-25^{\prime} \mathrm{W}\right)$, Elizabeth Falls/Fond du Lac River (59-03'N; 105 -33'), Bonokoski Lake (59-44'N; 103 22 ' W), and Hara Lake (59-05'N; 102 03 'W) [Figure 1]. At Bonokoski Lake and Hara Lake, research was done both on foot and by canoe (approx. 50\% each). We portaged onto adjacent lakes, ponds and calmer, wider areas of water. The absence of groups of tall trees and shrubs gave us excellent views of distant bodies of water; hence the bias towards more observations of water-related bird species. At Fir Island, the largest island on Black Lake, most observations were made along the water-edges, with brief trips into the intermittent evergreen forests and muskegs of the interior. 


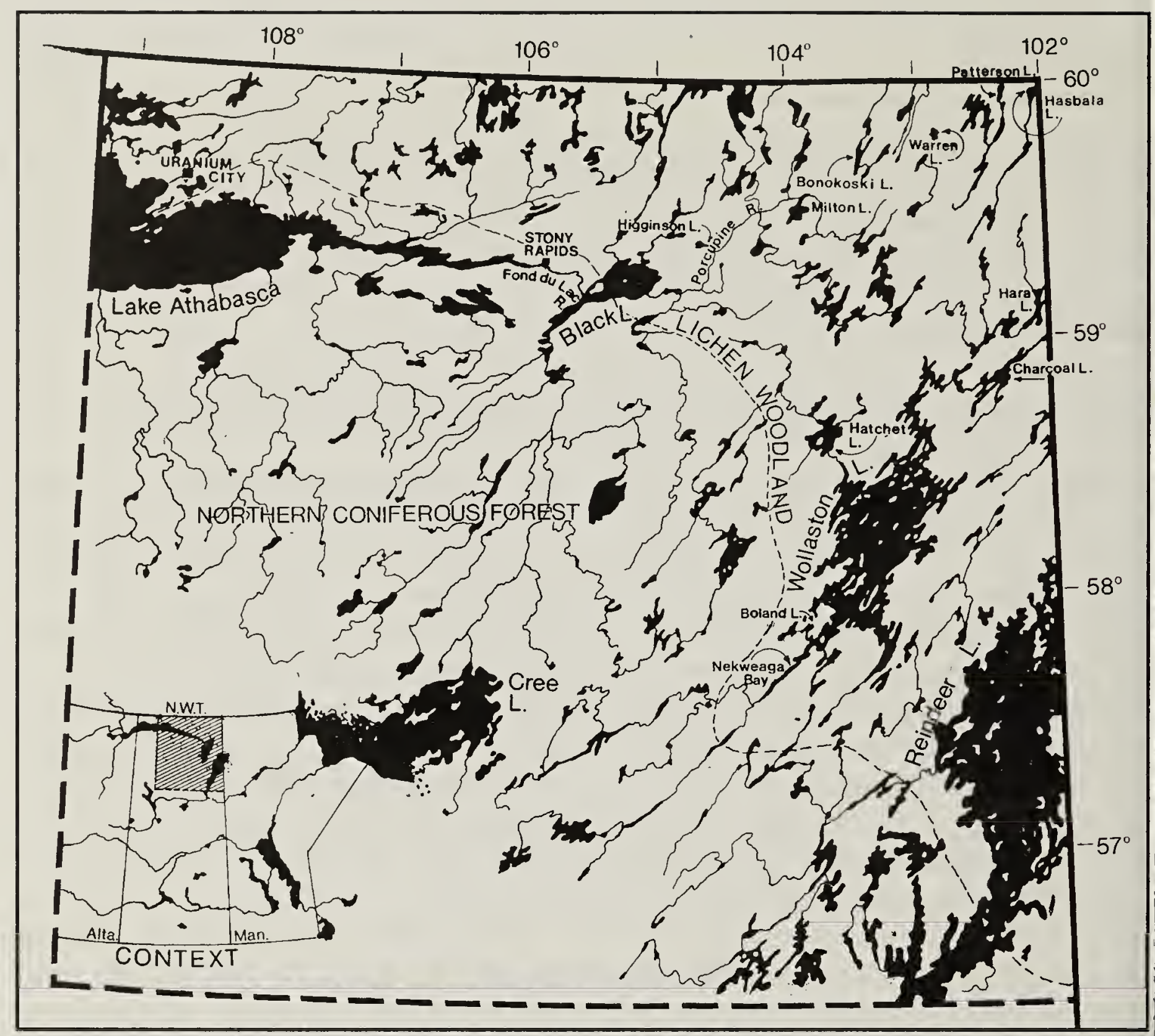

Figure 1 - Wayne Renaud

Neither Bonokoski Lake nor Hara Lake was visited by Nero ${ }^{3,4}$. All areas visited during this study are located within the 'sub-Arctic avifauna' zone and within the 'Lichen Woodland' vegetation zone. Forty-eight species were recorded during our visit ${ }^{4}$.

Significant breeding records are presented here for Common and Redbreasted Mergansers, Ring-necked Duck, Bufflehead, Black Scoter and Arctic Tern. Observations of Osprey, Rough-legged Hawk and Red-breasted Nuthatch further clarify the status of this species in this area.

Abbreviations used in the following species accounts: $a d=a d u l t ; ~ y=f l i g h t l e s s$ young; imm=flying juvenile; $y r=y e a r ;$
$\mathrm{Ag}=$ August; date format: $\mathrm{Ag}$ 15=month day.

\section{SPECIES LIST}

\section{Common Loon}

Hara Lake [2,1 ad +1y, 3=7-Ag 16;1ea - Ag 14, 15, 17 and 18; flock of $5-\mathrm{Ag}$ 19]

\section{Canada Goose}

Black Lake/Fir Island [flock of 15-Ag 14]; Bonokoski Lake [flock of 76-Ag 20]

\section{Mallard}

Black Lake/Fir Island [1 female-Ag 9]; Elizabeth Falls [1 female-Ag 10].

\section{Ring-necked Duck}

Hara Lake [1 female-14-15 Ag; one 
group of 8 females +18 flightless $y-$ Ag 16). Nero cites two June records for Wollaston lake with no direct evidence of breeding; both Godfrey and Smith show the nearest confirmed breeding record for central Reindeer Lake $200 \mathrm{~km}$ to south ${ }^{4,2,6}$.

\section{Lesser Scaup}

Hara Lake 11 female +8 flightless y$\mathrm{Ag} \mathrm{16]}$. Godfrey indicated that the southwestern edge of the breeding range of the Greater Scaup is located on the 60th parallel of latitude (the N.W. T. border), a mere $30 \mathrm{~km}$ north of the north end of Bonokoski Lake ${ }^{2}$. Great care was taken to correctly identify this female scaup, because of the possibility of recording greater Scaup nesting in this area. No greater Scaup were identified by Nero, but he did record "Lesser Scaup" and scaup species in most areas visited, and all these accounts are listed together under 'Lesser Scaup'. To date there appear to be no confirmed breeding records of Greater Scaup for Saskatchewan (Smith).

\section{Surf Scoter}

Hara Lake [1 female with six flightless young-Ag 16]; carefully watched for 20 minutes at distances down to $20 \mathrm{~m}$ with full front lighting. Identifying field marks included the two strong white spots on sides of the dark head of the female and young, and the lack of a white patch on the female when she fluttered her wings. Nero recorded two females at Hasbala Lake on 29 July 1962 an found them to be common breeders in Lake Athabasca area $^{3}$. Between 9 and 14 July 1963, Nero cited three observations of this species: two females together, a mated pair, and a female behaving as though it had a nest nearby-but with no definite breeding record for Hasbala Lake. In other areas of northern Saskatchewan Nero provided scattered records of Surf Scoters, some of which were exhibiting breeding behaviour: Stony Rapids, Black Lake, Milton Lake, Wollaston Lake and Reindeer Lake ${ }^{3,4}$. Secoy and Maw recorded two broods at Boland Lake on 6 and 8 on July 5, 1977. Smith cited confirmed breeding records only for Reindeer and Southern Wollaston Lakes. The latter location, $180 \mathrm{~km}$ southwest of Hara Lake (presumably referring to Secoy and May's two records), is the nearest location of a definite breeding record ${ }^{5}$. This Hara Lake breeding record thus represent one of only five verified breeding records for all of northeastern Saskatchewan?

\section{Bufflehead}

Hara Lake [1 female +6y-Ag 16]. Nero recorded a brood at Hasbala Lake 110 $\mathrm{km}$ due north near the boundary of Manitoba and N.W, $T^{4}$, Smith acknowledges Nero's record, as well as citing additional confirmed records of breeding for southern Reindeer Lake. central Wollaston Lake, and Little Gull Lake south of Lake Athabasca ${ }^{3,6}$. This current record fills the gap in between these four breeding areas in northern Saskatchewan.

\section{Common Merganser}

Black Lake [1 female + 6 y-Ag 15; female + 5y-Ag 16]. Nero cites one breeding record for the area between Stony Lake and Woodcock Rapids. These may be the first confirmed breeding records for Black Lake ${ }^{4}$.

\section{Red-breasted Merganser}

Elizabeth Falls [group of 5 males; 1 female +8 flightless $\mathrm{y}-\mathrm{Ag} 10$ ]; Hara Lake [1 female with 6 flightless y - Ag 16]. Nero recorded this species in most lakes surveyed but with no definite breeding records; he, does however, cite one nest record in Buchanan for Reindeer Lake [from July 12, 1914overlooked in Smith] $]^{4,17}$. However Smith cited what appears to be a confirmed breeding record for Hatchet Lake, 110 
km southeast of Hara Lake ${ }^{7}$. Secoy and Maw, recorded them on Boland Lake, southwest of Wollaston Lake, but with no evidence of breeding ${ }^{6}$. This Hara Lake record is likely, then only the second confirmed breeding record for northeastern Saskatchewan.

\section{Osprey}

Black Lake-Fir Island [1-Ag 9]; Hara Lake [1-Ag 15]. Nero, on August 1 , 1962, recorded a single bird at Hasbala Lake; however, none was observed there during 21 days of observations in $1963^{3}$. Secoy and Maw cited four records for the southern Wollaston Lake region ${ }^{6}$. This Hara Lake sighting may provides the second record for extreme northeastern Saskatchewan.

\section{Bald Eagle}

Bonokoski Lake [1 ad-Ag 15].

\section{Sharp-shinned Hawk}

Stony Rapids [1-24 Ag].

\section{Rough-legged Hawk}

Hara Lake [1-Ag 18]. The only definite record for extreme northeastern Saskatchewan was made at Hasbala Lake by Nero: a pair noted 31 July 1962 with reference to potential breeding habitat in nearby cliffs, though no nest was found ${ }^{3,4}$. Smith interpreted Nero's sighting as a confirmed breeding record, and further suggested that this was the only area in Saskatchewan where the species has nested?.

\section{Semipalmated Plover}

Stony Rapids [1-24 Ag]. Not recorded by Nero, but a small population nests in the sand dunes south of Lake Athabasca.

\section{Lesser Yellowlegs}

Bonokoski Lake [1-Aug 22].

\section{Solitary Sandpiper}

Hara Lake [1_Ag16; calling in flight- very agitated-then perched on top of a spruce and continued to calling until we left the area fifteen minutes later]. Nero and Secoy and Maw found them to be regular, and likely breeding, in most areas which they surveyed in the northeastern Saskatchewan ${ }^{4,6}$.

\section{Spotted Sandpiper}

Hara Lake [1-Ag 16].

\section{Least Sandpiper}

Black Lake/Fir Island [9-Ag 9]; Bonokoski Lake [1-Ag 21].

\section{Baird's Sandpiper}

Black Lake/Fir Island [1-Ag 9]. Nero listed two records from Reindeer Lake.

\section{Common Snipe}

Stony River [2-Ag 24].

\section{Ring-billed Gull}

Black Lake/Fir Island [8-Ag 9].

\section{Herring Gull}

Black Lake/Fir Island [10—Ag 9]; Hara Lake 91 first-yr imm-Ag 17-20]; Stony Rapids $93 \mathrm{ad}+4$ flying imm-4Ag].

\section{Arctic Tern and unidentified terns}

White terns were regularly seen during our visit but only two definite identifications were made: Black Lake/ Fir Island (3-Ag 8); Bonokoski Lake/ Tern Island [colony of $50+$ mixed adults and recently-fledged young; the remains of an undetermined number of nests were found on a bare, stony area on highest part of the island; we found one immature tern which was not yet old enough to fly-Ag 22]. Unidentified white terns were recorded as follows: Black Lake/ Fir Island [3 - 4; Ag 9-10]; Hara Lake [6-Ag 15; 2-Ag 16]; Bonokoski Lake [8-Ag 20; 1-Ag 21]; Stony Rapids [5-Ag 24]. Two nearby colonies were documented in Nero ${ }^{4}$. In 1964 , his team discovered a colony of 45 pairs on an island in Milton Lake 
approximately $32 \mathrm{~km}$ southwest of our Bonokoski Lake colony. On July 9, 1963, a group of three pairs were found nesting on a barren ridge at Patterson Lake, approximately $50 \mathrm{~km}$ eastnortheast of Bonokoski Lake. Nero did not record any Arctic Terns on Black Lake, but did see one flock of four on the Fond du Lac River which flows into Lac Lake ${ }^{4}$. Smith did not acknowledge Nero's sightings from northeastern Saskatchewan as confirmed breeding records, but he cited four other records for extreme northwestern Saskatchewan in the vicinity of Lake Athabasca where Nero found them nesting in 1960 and $1961^{7,3}$. Secoy and Maw identified a single bird at Boland Lake at 12 June $1977^{6}$.

\section{Common Nighthawk}

Bonokoski Lake [1-Ag 22]; Lefty Falls/ Stony Rapids [20 in flock Ag 23].

\section{Belted Kingfisher}

Black Lake [1 or 2 each day from $\mathrm{Ag}$ 8-13].

\section{Black-backed Woodpecker}

Black Lake/Fir Island [ 1 female-Ag10]; Bonokoski Lake[1 male-Ag 20].

\section{Northern Flicker}

Hara Lake [1-Ag 15].

\section{Cliff Swallow}

Lefty Falls/Stony Rapids [2-Ag 23].

\section{Barn Swallow}

-efty Falls/Stony Rapids [10-Ag 23].

\section{Gray Jay}

Black Lake/Fir Island [1-Ag 11 and 12]; Hara Lake [1-3-Ag 16-19];Bonokoski -ake [1-Ag 21 and 23].

\section{Common Raven}

Stony Rapids [4-Ag 9]; Elizabeth Falls 4-Ag 10-13]; Hara Lake[2-Ag 14-17]; Ponokoski Lake[1-Ag 20];Stony
Rapids [flock of 20Ag 24 ].

\section{Boreal Chickadee}

Hara Lake[1-Ag 16; groups of two and three-Ag 17 and 18; 1-Ag 20]; Bonokoski Lake [groups of 1and 3-Ag 21;4-Ag 22].

\section{Red-breasted Nuthatch}

Hara Lake[1-Ag 15 and 16]. Not recorded in $\mathrm{Nero}^{3,4}$. Smith showed the nearest sighting, a possible breeding record, as northern Reindeer Lake, 120 $\mathrm{km}$ to the south of Hara Lake ${ }^{7}$. Secoy and Maw found several pairs and groups of up to 5 at Boland Lake from 5 June to 16 July $1977^{6}$. This Hara Lake sighting represents the most northeasterly record for Saskatchewan.

\section{American Robin}

Hara Lake[1==Ag 15]; Bonokoski Lake[1-Ag 22 and 23].

\section{Yellow-rumped Warbler}

Black Lake[3-Ag 11];Bonokoski Lake[1-Ag 20 and 21].

\section{Palm Warbler}

Stony Rapids[1-Ag 24].

\section{Blackpoll Warbler}

Hara Lake[2-Ag 17].

\section{Northern Waterthrush}

Stony Rapids[1-Ag 24].

\section{Savannah Sparrow}

Bonokoski Lake[1-Ag 21].

\section{Fox Sparrow}

Bonokoski Lake[1-Ag 16].

\section{Lincoln's Sparrow}

Black Lake[1—Ag 11];Hara Lake[1—Ag 17].

\section{White-throated Sparrow}

Black Lake[1-Ag 11]. 


\section{White-crowned Sparrow}

Hara Lake[1-Ag 15 and 16].

\section{Dark-eyed Junco}

Elizabeth Falls[15-Ag 10]; Hara Lake[1-Ag 13].

\section{Rusty Blackbird}

Hara Lake[10-Ag 16]; Stony Rapids[3-Ag 24].

\section{Pine Grosbeak}

Hara Lake[groups of 1,1 and 6-Ag 15].

\section{Common Redpoll}

Hara Lake[flock of 50-Ag 14; flock of 100-Ag 15; flock of 10-Ag 16; flocks of 6,15 and 18-Ag 17]; Black Lake[flock of 6-Ag 20].

\section{Acknowledgements}

I thank Robert Wapple, Guy Wapple and Allan Smith for reviewing the initial manuscript and encouraging me to publish these forgotten records.

1. BUCHANAN, A. 1920. Wildlife in Canada. McClelland, Goodchild and Stewart Ltd. Toronto.
2. GODFREY, E. 1986. The Birds of Canada. National Museum of Canada Bulletin No. 203.

3. NERO, R.W. 1963. Birds of the Lake Athabasca Region, SK. Special; Publication No. 5, Saskatchewan Natural History Society, Regina SK.

4. NERO, R.W. 1967. Birds of Northeastern Saskatchewan. Special; Publication No. 6, Saskatchewan Natural History Society, Regina SK.

5. RICHARDS, J.K. and K.I. FUNG. 1969 Atlas of Saskatchewan. Department of Geography, University of Saskatchewan, Saskatoon, SK.

6. SECOY, D.M. and E. MAW 1982. Notes on the Birds of Wollaston Lake Region, Saskatchewan, Summer 1977. Blue Jay 40:90-96.

7. SMITH, A. 1996. Atlas of Saskatchewan Birds. Special; Publication No. 22, Manly Callin Series No. 4, Saskatchewan Natural History Society, Regina SK.

Of 77 Common Loons found dead in New England, more than half had died from lead poisoning, and half of these had eaten lead fishing sinkers. Lead sinkers are banned in great Britain and the Environmental Protection agency is investigating whether they should be banned in the United States. 